\title{
Comparison of Job Position Based Promotion Using: VIKOR, ELECTRE And Promethee Method
}

\author{
Akmaludin \\ Information System Department \\ STMIK Nusa Mandiri Jakarta \\ Jakarta, Indonesia \\ akmaludin.akm@nusamandiri.ac.id \\ Santoso Setiawan \\ AMIK BSI Jakarta \\ Computer Technic Department \\ Jakarta, Indonesia \\ santoso.sts@nusamandiri.ac.id
}

\author{
Sulistianto SW \\ Information System Department \\ STMIK Nusa Mandiri Jakarta \\ Jakarta, Indonesia \\ sulistianto.sow@nusamandiri.ac.id \\ Hendra Supendar \\ STMIK Nusa Mandiri Jakarta \\ Technic Informatic Department \\ Jakarta, Indonesia \\ hendra.hds@nusamandiri.ac.id
}

\author{
Adjat Sudradjat \\ Information Management Department \\ AMIK BSI Jakarta \\ Jakarta, Indonesia \\ adjat.ajt@bsi.ac.id \\ Yopi Handrianto \\ AMIK BSI Bandung \\ Computer of Accounting Department \\ Bandung, Indonesia \\ yopi.yph@bsi.ac.id
}

\author{
Rusdiansyah \\ Information Management Department \\ AMIK BSI Jakarta \\ Jakarta, Indonesia \\ rusdiansyah.rds@bsi.ac.id
}

\author{
Tuslaela \\ Information System Department \\ STMIK Nusa Mandiri Jakarta \\ Jakarta, Indonesia \\ tuslaela.tll@nusamandiri.ac.id
}

\begin{abstract}
The long-term prospect of the company's progress is determined by the quality of human resources (HR), The urgency to maintain the company's survival it takes a reliable and futuristic leader. Measuring tool that can be used is none other than the performance of human resources. Of course with potential leaders will provide the vision of the company's mission to grow and expand. Leadership selection process can be done with promotion positions based on performance preference. The purpose of this research is to conduct selection of performance promotion based on performance using Multi-Criteria Decision Making (MCDM) selection methods such as Analytic Hiererachy Process (AHP), VIKOR, ELECTRE, and Promethee, in addition to proving the result of a number of methods based on MCDM such as AHP for the determination of preferences data design, while for data analysis using three methods that will be compared the results of VIKOR, ELECTREE and Promethee. The measurable performance bases for promotional positions are viewed from Intelegency (IG), Panning (PL), Depandebility (DP), Reaction Behavior (RB), Failed Jobs (FJ), Quantity of Work $(\mathrm{QW})$, and Knowledge of Job (KJ). The results obtained provide an interpretation that the promethee method is closer to the actual results, while the vikor method is almost close to the results of truth and far away when compared with the electre method. Thus, it can be concluded that the best method for placing employee positions is promethee method.
\end{abstract}

Keyword - Multi-criteria, Preferences of Job Performance, Elimination Method, ELECTRE, VIKOR, Promethee.

\section{INTRODUCTION}

The quality of human resources is paramount to the progress of the company, because individualized expertise can be measured from individual performance [1], this is a very important thing as a benchmark in selecting a potential leader through the promotion process. Promotion of positions is an effort that must be done by the company to provide an opportunity for employees who have job performance to occupy a position higher than the occupation previously occupied and have greater authority and responsibility [1].

The purpose of this study is to compare the results of several methods to provide the best solution for achieving the objectives of the company and to compare the results of the promotion by using three methods, namely VIKOR, ELECTRE, and Promethee, how decisions are generated using the three methods. The three methods used to achieve performance appraisal goals, of course, require employees who have good performance appraisals that can work effectively and efficiently [2]. Good performance is just as an employee is able to demonstrate work behavior that leads to the achievement of company intent and purpose [2]. For that the company did many ways to improve employee performance including promotion of position for improvement of employee position, one of them using method Analytic Hierarchy Process (AHP) [3]. This research tries to perform a combination of methods to perform new solutions to the promotion process. The combination is a crystallization of Multi-Criteria Decision Making (MCDM) ie AHP and VIKOR, ELECTRE, and Promethee. Each method has its own function that can be collaborated to determine the final snap with the indexed result method with VIKOR. VIKOR can also be used for selecting personnel training [4] in addition to MCDM.

MCDM is one way used to analyze the criteria and tools alternative comparison depicted in the hierarchy of analysis on AHP. The MCDM method applied by means of iteration to obtain the eigenvector value and the result will be used to determine the preference of the criteria used in this discussion. MCDM is also included in the decision-making category by ranking [5]. Analytic Hierarchy Process (AHP) is a method for evaluating and selecting that simplifies complex problems 
simple by composing each level, the level being the goal, criteria, and alternative [6], [7], [8]. VIKOR became a widely-used collaboration with MCDM [9], Vikor is a ranking method that uses the index system to determine the best alternative [10], and other multi-criteria of ELECTRE and Promethee.

The performance appraisal used for promotion consists of seven criteria, each criterion has a special understanding in giving an assessment, there are variables that have the greatest value with the best value meaning (High is the Best) and there is a small value variable that implies the best value ( Low is the Best). [10]. The Compromise Ranking method, also known as the VIKOR, ELECTRE, and Promethee methods gives an alternative ranking and determines the solution called the most ideal compromise. In fact, this work considers few alternatives for simplicity, but this model can be used to evaluate more alternatives. Its main task is to compare a number of alternatives and choose the best [11].

\section{METHOD}

Employee job preferences in companies that are not mentioned determine the progress of the company, so that it requires a number of appropriate criteria to choose the best leader, this assessment is determined by company policy which is determined to be seven assessment criteria, by seeing competition outside these criteria to be a company decision to remain a company who is able to lead the market.

The collecting data, a leader has done a number of samples from employees with seven criteria that have been set and have been done by experts to give value to a number of employees. This has been done for several periods, then the average value of each employee is taken.

In this section describes the concept of Position Promotion, Analytic Hierarchy Process (AHP), Multi-Criteria Decision Making (MCDM) analysis, and the elimination process using VIKOR, ELECTREE, and Promethe methods.

\subsection{Promotion of Position.}

Promotion of position should be done with a number of assessment criteria, each criterion can be seen from some skills interests, which is the total of the results that can be accountable. While performance in work performance is the result of work in quality and quantity achieved by an employee in performing its duties according to the responsibility given to him [3], [12], [13].

The criteria used for promotion include seven criteria: (1) intelligence (IG); (2) Planning (PL); (3) Dependability (DP); (4) Reaction Behavior (RB); (5) Failed Jobs (FJ); (6) Quantity of Work (QW); (7) Knowledge of Job (KJ). Each criterion has two special rating categories, rating with High Is The Best (HB) meaning that the highest score is the best value or Low is The Best (LB) the lowest value is the best. For category of $\mathrm{HB}$ criteria are PL, QW, and KJ, while those belonging to LB criteria category are IG, DP, RB, and FJ. Each preference gives unequal meanings in its usage, the amount of preference can be interpreted as the best MAX value or it can be interpreted that the MIN value is the best.

\subsection{Analytic Hierarchy Process (AHP).}

The current multi-criteria decision-making method (MCDM) presents a valid alternative to weighting multiple criteria while enabling the participation of multiple stakeholders. Among them, the Analytical Hierarchy Process (AHP) makes decisions in a way that is easily understood by stakeholders and allows them to analyze independent subproblems by constructing problems in hierarchy and using pairwise comparisons [14]. The specificity of the AHP has an appropriate allocation in pairwise comparisons across the entire range of human activities, AHP [15], capable of handling both qualitative and quantitative problems [16] that apply to decomposed hierarchical modeling to facilitate solving complex problems [17] or variables in a hierarchical order, assigns numerical values to subjective considerations of the importance of each variable and synthesizes these considerations to determine which variables have the highest priority [2], [18].

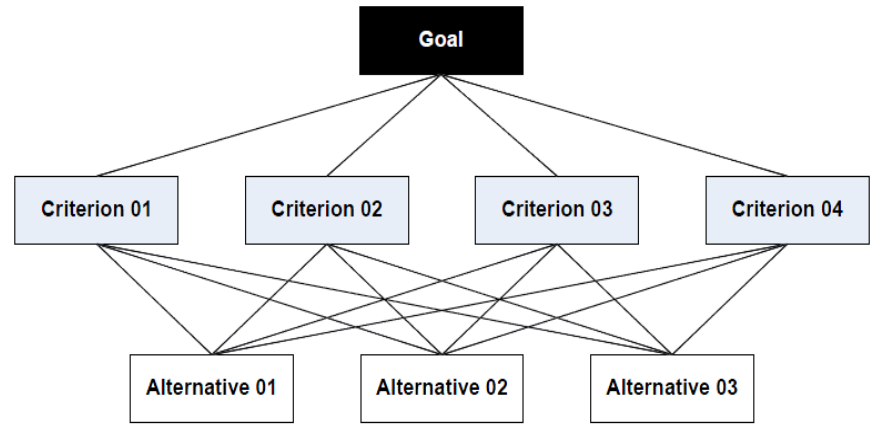

Fig. 1. Hierarchy for all level [19].

In this process AHP has a very important role to determine the value of the importance of each criterion as a preference measured based on the value of its importance in the form of a hierarchical model. Then arranged in pairwise matrix form.

\subsection{Multi-Criteria Decision Making (MCDM).}

Metode MCDM merupakan metode yang yang berbeda dan telah dibandingkan sebagian besar berdasarkan metode penyelesaian, algoritma, dan metode tertimbang [20].

The MCDM method is a different method and has been compared largely based on settlement methods, algorithms, and weighted methods [20].

Techniques such as MCDM that are multi-criteria are considered as one of the best ways and means to think and equate the level of some criteria for decision-making and deal with imprecision [21].

The MCDM method has proven to be widely used and has its own advantages in decision making which are the development of AHP [5], [10], [22], [23], [24]. MCDM is able to provide comparisons that generate rankings from each level of both criteria and alternatives. In this study the priority values generated from MCDM are used for preferences with multi-criteria VIKOR, ELECTREE, and Promethee. Some of the criteria of the VIKOR decision-making method are based as a combined function that represents the proximity to the ideal, derived from the compromise programming method. The linear normalization used by VIKOR to eliminate the unit 
of criterion function [5], thus the baseline data as the reference for determining the largest value and the smallest value as the range for determining the magnitude of normalization which is continuously operated with preferences obtained by AHP and MCDM methods, through the optimal eigenvector value of each criterion, note (Table 1 and Table 2).

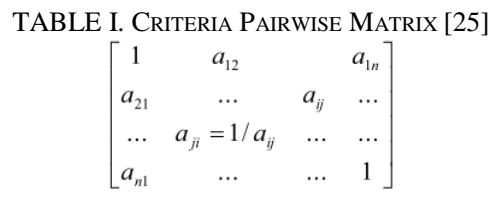

Where ai, $\mathrm{j}$ is the comparison between element $\mathrm{i}$ and $\mathrm{j}$ of the lower triangular matrix containing reciprocal mean [17], [25]. The role of MCDM in this case is to determine the value of each preferences that can be compared with AHP, while observation data is processed by VIKOR, ELECTRE, and Promehtee method. The end result of the criteria was obtained from instrumentation in the form of questionnaires by using MCDM with a number of iterations to obtain the optimal value of eigenvector, which then made the standard as the weight preference of the seven criteria used in this study.

\subsection{VIKOR.}

The VIKOR Method (Vise Kriterijumska Optimizacija I Kompromisno Resenje) is a method used for multi-criteria decision making [26].

The VIKOR method is performed to calculate the positive and negative ideal solution ratios [27] which provides a list of alternative ratings with the highest rating of VIKOR which is the result closest to the ideal solution. A number of equation have been simplified as VIKOR calculations such as

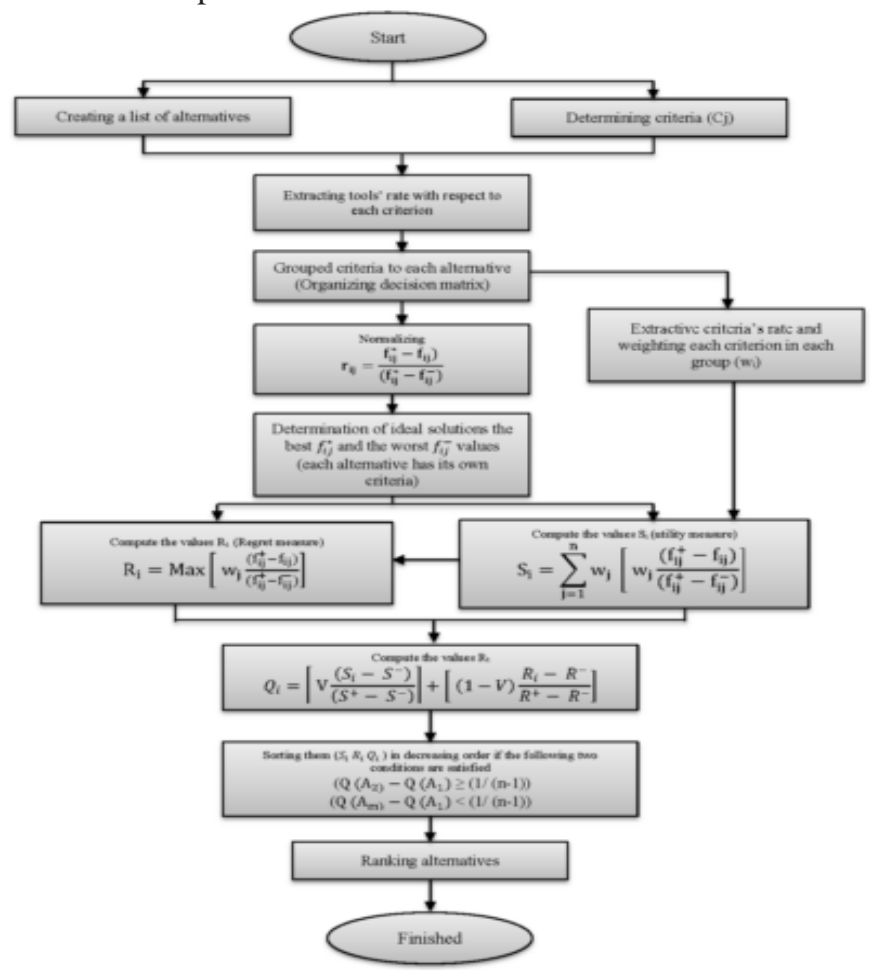

Fig. 2.The VIKOR Stage [8] determining the Normalization of a matrix listed in (equation-1), which is used to determine the exact location of the sample $\mathrm{R}(\mathrm{i}, \mathrm{j})$ of the specified range.

$$
\mathrm{R}_{\mathrm{ij}}=\frac{(X * j-X i j)}{\left(X * j-X^{\prime} j\right)}
$$

Rij: Normalization Matrix VIKOR,

$\mathrm{Xij}$ : The value of the sample data $\mathrm{i}$ criteria $\mathrm{j}$,

$\mathrm{X}^{*} \mathrm{j}$ : The Largest Value in one criteria,

$\mathrm{X}^{\prime} \mathrm{j}$ : The Smallest Value in one criterion,

i: The assessed employee (K1 ... K5),

$\mathrm{j}$ : Criteria used (seven criteria).

After the sample $R(i, j)$ is normalized, then the weight of the $\mathrm{Wj}$ criterion is multiplied by $\mathrm{R}(\mathrm{i}, \mathrm{j})$ summed into $\mathrm{Si}$ shown in (equation-2) and Ri represents the largest value of each row i seen in (equation-3).

$$
\begin{array}{ll}
\mathrm{S}_{\mathrm{i}} & =\sum_{j=1}^{n} \text { wj } x(\text { Rij }) \\
\mathrm{Ri} & =\operatorname{Max}_{\mathrm{j}}\left[\mathrm{w}_{\mathrm{j}} \times \mathrm{R}_{\mathrm{ij}}\right]
\end{array}
$$

After knowing the weight of each row, the dimensions of $\mathrm{Si}$, and $\mathrm{S} *$ the largest value of $\mathrm{S}, \mathrm{S}$ 'the smallest value of $\mathrm{S}, \mathrm{R} *$ the largest variable $R$ value and $R^{\prime}$ the smallest variable $R$ value, of all, can be done determination of the VIKOR Qi index, with the equation seen in (equation-4).

$$
\mathrm{Q}_{\mathrm{i}}=\left[\frac{S i-S^{\prime}}{S *-S^{\prime}}\right] \times \mathrm{v}+\left[\frac{R i-R^{\prime}}{R *-R^{\prime}}\right] \times(1-\mathrm{v})
$$

\subsection{ELECTRE}

The ELECTRE method is a concept of elimination from a normalized result through a function which is further downgraded to concordance and discordance to rank. The ELECTRE method has a basic understanding of the same data as a VICOR that has been normalized before with the rules The largest value is the best value or the smallest value is the best value.

Some steps must be taken to use the ELECTRE method seen in (Fig.3), MCDM combination poured into AHP and is a simplified way to be understood. Some of the equation used

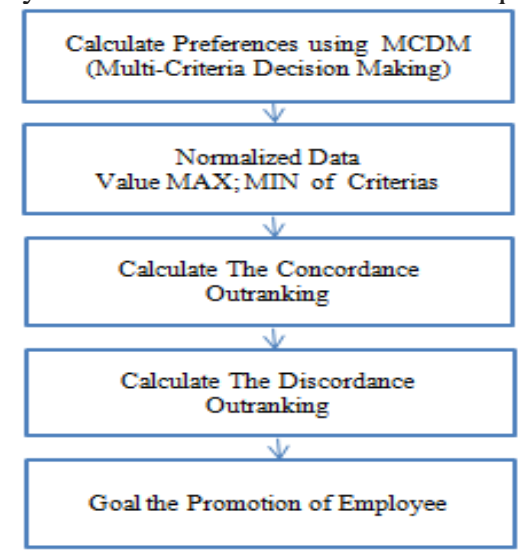

Fig. 3. Steph by Steph ELECTRE Method 
in the ELECTRE method come from to search for data normalization using (equation-5).

$$
\mathrm{R}_{\mathrm{ij}}=\frac{\left(X i j-X^{\prime} j\right)}{\left(X * j-X^{\prime} j\right)}
$$

Where, Rij : Matrix Normalization,

Xij : The Searching Number,

$\mathrm{X}^{*} \mathrm{j}$ : Biggest Number,

$\mathrm{X}^{\prime} \mathrm{j}$ : Lowest Number,

i : Assessed Employee (K1...K5)

$\mathrm{j}$ : Seven Criteria's.

While to find the value of concordance can use (equation6 ), whereas to find the amount of discordance can use (equation -7). The equation used should still pay attention to the value of MAX and MIN values of each preference set.

$$
\begin{aligned}
& C\left(i, i^{\prime}\right)=\sum_{j} w j, \text { where } R_{i, j}>R_{i^{\prime} j} \\
& D\left(i, i^{\prime}\right)=\sum_{j} w j, \text { where } R_{i, j}<R_{i^{\prime} j}
\end{aligned}
$$

So the end result can be searched by mathematical deduction of concordance and discordance resulting in a ranking of alternatives that can be decided.

\subsection{Promethee.}

Stages that must be known in Promethee there are some steph [28] namely:

Steph 1: Determination of deviations base on pairwise comparison.

Steph 2: Application of the preference function.

Steph 3: Calculation of an overall or global preference index.

Steph 4: Calculation of outranking flows the promethee-1 partial ranking (leaving flow dan entering flow)

Steph 5: Calculation of outranking flows the promethee-2 as complete ranking.

Promethee has a similar calculation process with ELECTRE, in terms of determining the magnitude of the matrix normalization, see (equation-8) to determine the normalization of the matrix. Other equation that can be used to analyze with the Promethee method in terms of aggregate determination of preference functions see (equation-9), leaving flow see (equation-10), entering flow see (equation11) which is a partially separate outcome. To combine it using the net flow view see (equation-12).

$$
\begin{aligned}
& \mathrm{R}_{\mathrm{ij}}=\frac{\left(X i j-X^{\prime} j\right)}{\left(X * j-X^{\prime} j\right)} \\
& \pi\left(\mathrm{i}, \mathrm{i}^{\prime}\right)=\left[\sum_{j=1}^{m} w j x \operatorname{Pj}\left(i, i^{\prime}\right)\right] / \sum_{j=1}^{m} w j \\
& \Phi^{+}(\mathrm{i})=\frac{1}{(n-1)} \sum_{i^{\prime}=1}^{n} \pi\left(i, i^{\prime}\right)
\end{aligned}
$$

$$
\begin{aligned}
& \Phi^{-}(\mathrm{i}) \quad=\frac{1}{(n-1)} \sum_{i^{\prime}=1}^{n} \pi\left(i, i^{\prime}\right) \\
& \Phi(\mathrm{i}) \quad=\Phi^{+}(\mathrm{i})-\Phi^{-}(\mathrm{i})
\end{aligned}
$$

\section{IMPLEMENTATION AND RESULTS}

The making of hierarchy is a total picture of the research that creates the concept of modeling solutions. The hierarchy is used as a basic understanding model consisting of three levels: (1) the level of goal, which is the main target of employee performance performances for promotion of positions in an agency; (2) criterion level, is a barometer to measure the number of criteria determined by the value as a preference of each criterion. The preference quantity is obtained based on the hierarchical model which is processed iteratively until there is no difference to the eigenvector value, the use of this eigenvector value is the optimum value and will be used as the reference for the multiplication of the criteria with the result of normalization in multi-criteria calculation using VIKOR, ELECTRE, and Promethee.

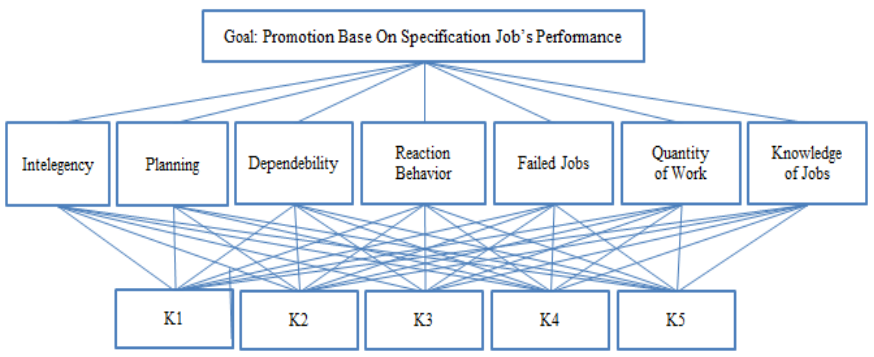

Fig. 3. Hierarchy of Position Based Promotion Model.

Multi-Criteria with AHP, used to determine the preference for the magnitude of each criterion, known under the optimal eigenvector and obtained through the iteration stage in the absence of the difference with the previous eigenvector, is the importance of the eigevector value [29]. For the value of criterion preferences, note (TABLE II).

TABLE II. Value Of Criteria Preference

\begin{tabular}{cccccccc}
\hline Criteria & IG & PL & DP & RB & FJ & QW & KJ \\
\hline Value & 0.23 & 0.16 & 0.19 & 0.15 & 0.07 & 0.11 & 0.09 \\
\hline
\end{tabular}

In the (TABLE II) illustrates the preferences of the seven criteria that serve as the basis for the interest of observations through the MCDM-AHP method and serve as a benchmark for the calculation process with the three methods VIKOR, ELECTRE, and Promethee.

TABLE III. Observation Data VIKOR, Electre, and Promethee

\begin{tabular}{rrrrrrrr}
\hline & IT & PL & DP & RB & FJ & QW & \multicolumn{1}{l}{ KJ } \\
\hline K1 & 74.05 & 64.67 & 73.94 & $\mathbf{8 4 . 3 3}$ & 14.02 & $\mathbf{1 8 . 5 9}$ & $\mathbf{9 . 6 3}$ \\
\hline K2 & 86.03 & $\mathbf{9 4 . 2 3}$ & 84.23 & 73.25 & $\mathbf{1 3 . 4 5}$ & $\mathbf{9 7 . 8 1}$ & 15.04 \\
\hline K3 & 66.73 & 83.18 & $\mathbf{9 4 . 6 7}$ & 48.85 & $\mathbf{2 7 . 8 4}$ & 30.59 & 27.66 \\
\hline K4 & $\mathbf{9 9 . 5 0}$ & $\mathbf{6 0 . 7 5}$ & 75.22 & 64.84 & 15.92 & 22.43 & $\mathbf{9 9 . 5 2}$ \\
\hline K5 & $\mathbf{4 3 . 1 8}$ & $\mathbf{7 6 . 3 5}$ & $\mathbf{6 2 . 4 5}$ & $\mathbf{5 6 . 5 2}$ & 16.58 & 61.77 & 45.27 \\
\hline
\end{tabular}


The data shown in (TABLE III) is the data that becomes the basis of promotion research positions that will be compared with three methods namely VIKOR, ELECTRE, and Promethee, from five employees (K1-K5) for job position base promotion. The data must be specified first MAX value and MIN value, (note the number that is thickened) that made the process of normalization parameters.

\subsection{VIKOR Method.}

The first stage of the VIKOR method is to determine the normalization matrix, see (TABLE IV).

TABLE IV. NORMALIZATION WiTh VIKOR

\begin{tabular}{cccccccc}
\hline & LB & HB & LB & LB & LB & HB & HB \\
\hline & IG & PL & DP & RB & FJ & QW & KJ \\
\hline K1 & 0.55 & 0.88 & 0.36 & 1.00 & 0.04 & 1.00 & 1.00 \\
\hline K2 & 0.76 & 0.00 & 0.68 & 0.69 & 0.00 & 0.00 & 0.94 \\
\hline K3 & 0.42 & 0.33 & 1.00 & 0.00 & 1.00 & 0.85 & 0.80 \\
\hline K4 & 1.00 & 1.00 & 0.40 & 0.45 & 0.17 & 0.95 & 0.00 \\
\hline K5 & 0.00 & 0.53 & 0.00 & 0.22 & 0.22 & 0.45 & 0.60 \\
\hline
\end{tabular}

With the result data normalized through VIKOR, then determine the value of $\mathrm{Si}$ that can be done with the equation that existed in (equation -2) with the calculation results can be seen in (TABLE V).

TABLE V. Multiplication Quality And Normalization.

\begin{tabular}{cccccccc}
\hline BOBOT & 0.24 & 0.15 & 0.18 & 0.16 & 0.06 & 0.10 & 0.11 \\
\cline { 2 - 8 } & IG & PL & DP & RB & FJ & QW & KJ \\
\hline K1 & 0.132 & 0.132 & 0.064 & 0.160 & 0.002 & 0.100 & 0.110 \\
\hline K2 & $\mathbf{0 . 1 8 3}$ & 0.000 & 0.122 & 0.110 & 0.000 & 0.000 & 0.103 \\
\hline K3 & 0.100 & 0.050 & 0.180 & 0.000 & 0.060 & 0.085 & 0.088 \\
\hline K4 & $\mathbf{0 . 2 4 0}$ & 0.150 & 0.071 & 0.072 & 0.010 & 0.095 & 0.000 \\
\hline K5 & 0.000 & 0.080 & 0.000 & 0.035 & 0.013 & 0.045 & 0.066 \\
\hline
\end{tabular}

The next step determines the magnitude of each of the $\mathrm{Si}$ and $\mathrm{Ri}$ values. To obtain the value of $\mathrm{Si}$ can use (equation-2), whereas to determine the value of $\mathrm{Ri}$ can use the equation in (equation -3). The result of the value of $\mathrm{Si}$ and $\mathrm{Ri}$ values can be seen in (TABLE VI).

TABLE VI. VAlue OF $\mathrm{Si}$ and $\mathrm{Ri}$

\begin{tabular}{ccc}
\hline A1ternative & Si & Ri \\
\hline K1 & 0.70 & 0.16 \\
\hline K2 & 0.52 & 0.18 \\
\hline K3 & 0.56 & 0.18 \\
\hline K4 & 0.64 & 0.24 \\
\hline K5 & 0.24 & 0.07 \\
\hline
\end{tabular}

At (TABLE VI) is the accompaniment of each of the Si and $\mathrm{Ri}$ values which in turn determine the VIKOR index to determine the ranking of selected alternatives. The results of the VIKOR index can determine the synthesize of the ranking of some alternatives, see (TABLE VII).

TABLE VII. QUANTITY OF Q VALUE AND RANG VIKOR

\begin{tabular}{ccccc}
\hline A1ternatives & S & R & Q & Ranking \\
\hline K1 & $\mathbf{0 . 7 0}$ & 0.160 & 0.77 & 4 \\
\hline K2 & 0.52 & 0.183 & 0.64 & 2 \\
\hline K3 & 0.56 & 0.180 & 0.68 & 3 \\
\hline K4 & 0.64 & $\mathbf{0 . 2 4}$ & 0.93 & 5 \\
\hline K5 & $\mathbf{0 . 2 4}$ & $\mathbf{0 . 0 7}$ & 0.00 & 1 \\
\hline
\end{tabular}

\subsection{ELECTRE Method}

With reference to (TABLE III), the ELECTRE method can calculate Concordance and Discordance by using a comparison of criteria functions, note (TABLE VIII). Thus, the value of Concordance and Discordance can be simplified, see (TABLE IX).

TABLE VIII. Concordance And Discordance CRiterian Function.

\begin{tabular}{|c|c|c|c|c|c|c|c|c|}
\hline & s/, & IG & PL & DP & $\mathrm{RB}$ & FJ & QW & $\mathrm{KJ}$ \\
\hline & gtion & 0.24 & 0.15 & 0.18 & 0.16 & 0.06 & 0.1 & 0.11 \\
\hline \multirow{4}{*}{$\mathrm{K} 1$} & $\mathrm{C}(1,2)$ & 0.21 & 0.00 & 0.32 & 0.00 & 0.00 & 0.00 & 0.00 \\
\hline & $\mathrm{C}(1,3)$ & 0.00 & 0.00 & 0.64 & 0.00 & 0.96 & 0.00 & 0.00 \\
\hline & $\mathrm{C}(1,4)$ & 0.45 & 0.12 & 0.04 & 0.00 & 0.13 & 0.00 & 0.00 \\
\hline & $\mathrm{C}(1,5)$ & 0.00 & 0.00 & 0.00 & 0.00 & 0.18 & 0.00 & 0.00 \\
\hline \multirow{4}{*}{$\mathrm{K} 2$} & $\mathrm{C}(2,1)$ & 0.00 & 0.88 & 0.00 & 0.31 & 0.04 & 1.00 & 0.06 \\
\hline & $\mathrm{C}(2,3)$ & 0.00 & 0.33 & 0.32 & 0.00 & 1.00 & 0.85 & 0.00 \\
\hline & $\mathrm{C}(2,4)$ & 0.24 & 1.00 & -0.28 & 0.00 & 0.17 & 0.95 & 0.00 \\
\hline & $\mathrm{C}(2,5)$ & 0.00 & 0.53 & 0.00 & 0.00 & 0.22 & 0.45 & 0.00 \\
\hline \multirow{4}{*}{$\mathrm{K} 3$} & $\mathrm{C}(3,1)$ & 0.13 & 0.55 & 0.00 & 1.00 & 0.00 & 0.15 & 0.20 \\
\hline & $\mathrm{C}(3,2)$ & 0.34 & 0.00 & 0.00 & 0.69 & 0.00 & 0.00 & 0.14 \\
\hline & $\mathrm{C}(3,4)$ & 0.58 & 0.67 & 0.00 & 0.45 & 0.00 & 0.10 & 0.00 \\
\hline & $\mathrm{C}(3,5)$ & 0.00 & 0.00 & 0.00 & 0.22 & 0.00 & 0.00 & 0.00 \\
\hline \multirow{4}{*}{$\mathrm{K} 4$} & $\mathrm{C}(4,1)$ & 0.00 & 0.00 & 0.00 & 0.55 & 0.00 & 0.05 & 1.00 \\
\hline & $\mathrm{C}(4,2)$ & 0.00 & 0.00 & 0.00 & 0.24 & 0.00 & 0.00 & 0.94 \\
\hline & $\mathrm{C}(4,3)$ & 0.00 & 0.00 & 0.60 & 0.00 & 0.83 & 0.00 & 0.80 \\
\hline & $\mathrm{C}(4,5)$ & 0.00 & 0.00 & 0.00 & 0.00 & 0.05 & 0.00 & 0.60 \\
\hline \multirow{4}{*}{ K5 } & $\mathrm{C}(5,1)$ & 0.55 & 0.35 & 0.36 & 0.78 & 0.00 & 0.55 & 0.40 \\
\hline & $\mathrm{C}(5,2)$ & 0.76 & 0.00 & 0.68 & 0.47 & 0.00 & 0.00 & 0.34 \\
\hline & $\mathrm{C}(5,3)$ & 0.42 & -0.20 & 1.00 & 0.00 & 0.78 & 0.39 & 0.20 \\
\hline & $\mathrm{C}(5,4)$ & 1.00 & 0.47 & 0.40 & 0.23 & 0.00 & 0.50 & 0.00 \\
\hline
\end{tabular}

TABLE IX. CONCORdance ANd Discordance

\begin{tabular}{cccccc}
\hline & K1 & K2 & K3 & K4 & K5 \\
\hline K1 & & 0.42 & 0.24 & 0.63 & 0.06 \\
\hline K2 & 0.53 & & 0.49 & 0.73 & 0.31 \\
\hline K3 & 0.76 & 0.54 & & 0.65 & 0.16 \\
\hline K4 & 0.37 & 0.27 & 0.35 & & 0.17 \\
\hline K5 & 0.94 & 0.69 & 0.84 & 0.83 & \\
\hline
\end{tabular}

Note (TABLE IX), the value of the concordance is the value of the upper triangle, while the discordance value in the lower triangle will be obtained by determining the ranking of the ELECTRE method, see (TABLE X).

TABLE X. Alternative RANKIng ELECTRE

\begin{tabular}{cccrrr}
\hline Employee & Concordance & Discordance & \multicolumn{2}{c}{ C-D } & Ranking \\
\hline K1 & 1.35 & 2.60 & -1.25 & 4 \\
\hline K2 & 2.06 & 1.92 & 0.14 & 3 \\
\hline K3 & 2.11 & 1.92 & 0.19 & 2 \\
\hline K4 & 1.16 & 2.84 & -1.68 & 5 \\
\hline K5 & 3.30 & 0.70 & 2.60 & 1 \\
\hline
\end{tabular}

\subsection{Promethee Method.}

With reference to (TABLE III) which is an observation table, the processed data using the promethee method will assign aggregate preference functions first, note (TABLE XI).

TABLE XI. Aggregate Promethee Preferences Function

\begin{tabular}{cccccc}
\hline & $\mathrm{K} 1$ & $\mathrm{~K} 2$ & $\mathrm{~K} 3$ & $\mathrm{~K} 4$ & $\mathrm{~K} 5$ \\
\hline $\mathrm{K} 1$ & & 0.110 & 0.189 & 0.139 & 0.012 \\
\hline $\mathrm{K} 2$ & 0.306 & & 0.278 & 0.332 & 0.151 \\
\hline $\mathrm{K} 3$ & 0.303 & 0.195 & & 0.320 & 0.032 \\
\hline $\mathrm{K} 4$ & 0.178 & 0.120 & 0.245 & & 0.058 \\
\hline $\mathrm{K} 5$ & 0.463 & 0.404 & 0.402 & 0.470 & \\
\hline
\end{tabular}


The end result of the promethee, determined from the Leaving Flow and the Entering Flow that is still partial, so combined with the mathematical process to rank, take note (TABLE XII).

TABLE XII. PROMENTHEE RANKING

\begin{tabular}{rrrrr}
\hline Alt & Leaving Flow & Entering Flow & \multicolumn{1}{c}{ C-D } & Ranking \\
\hline K1 & 0.113 & 0.312 & -0.200 & 5 \\
\hline K2 & 0.267 & 0.207 & 0.059 & 2 \\
\hline K3 & 0.213 & 0.278 & -0.066 & 3 \\
\hline K4 & 0.150 & 0.315 & -0.165 & 4 \\
\hline K5 & 0.435 & 0.063 & 0.371 & 1 \\
\hline
\end{tabular}

Comparison Results Promotion based performance performance using three methods of VIKOR, ELECTRE, and Promethee can be seen in (TABLE XIII).

TABLE XIII. RANGKING Of VIKOR, ELECTRE, and PrometheE.

\begin{tabular}{cccc}
\hline \multirow{2}{*}{ Alternatives } & \multicolumn{3}{c}{ Promotion Base Position } \\
\cline { 2 - 4 } & VIKOR & ELECTRE & Promethee \\
\hline K1 & 0.770 & -1.250 & -0.200 \\
\hline K2 & 0.636 & 0.140 & 0.059 \\
\hline K3 & 0.678 & 0.190 & -0.066 \\
\hline K4 & 0.933 & -1.680 & -0.165 \\
\hline K5 & 0.000 & 2.600 & 0.371 \\
\hline Ranking & $5-2-3-1-4$ & $5-3-2-1-4$ & $5-2-3-4-1$ \\
\hline
\end{tabular}

The results obtained provide an interpretation that the promethee method is closer to the actual results, while the vikor method is almost close to the results of truth and far away when compared with the electre method. Thus, it can be concluded that the best method for placing employee positions is the promethee method.

\section{CONCLUSION}

The conclusions that can be drawn from Job Promotion for performance-based employees appear to be varied, with the VIKOR method in sequential first rank K5-K2-K3-K1-K4. with the weight in sequence is $0.0 ; 0.636 ; 0.678 ; 0.77$, and 0.93. While the results of ranking with the method of ELECTREE in sequence is K5-K3-K2-K1-K4, with consecutive weights $2.6 ; 0.19 ; 0.14 ;-1.25$; and -1.68 . And the result of ranking with Promethee method in sequence is K5K2-K3-K4-K1, with consecutive weights 0.371 ; 0.059; -0.066; -0.165 , and -0.2 . The results obtained provide an interpretation that the promethee method is closer to the actual results, while the vikor method is almost close to the results of truth and far away when compared with the electre method. Thus, it can be concluded that the best method for placing employee positions is the promethee method.

\section{REFERENCES}

[1] B. Prabowo, "Motivasi Kerja Dan Prestasi Kerja ( Studi Pada Karyawan PT Telkom Indonesia Witel Jatim Selatan Malang )," J. Adm. Bisnis, vol. 32, no. 1, pp. 106-113, 2016.

[2] I. Eva Solita Pasaribu, "Sitem Pendukung Keputusan Promosi Jabatan Karyawan Dengan Metode Analytycal Hierarchy Process (AHP) Studi Kasus Pada PT.Selular Global Net Medan," Teknol. Dan Sist. Inf., no. AHP, pp. 71-78, 2015.

[3] B. S. Riza and J. Irianti, "Sistem Promosi Jabatan Dengan
Menggunakan Analytic Network Process ( Studi Kasus di PT . Maxi Media )," Konf. Nas. Sist. Inform., pp. 9-10, 2015.

[4] M. F. El-santawy, "A VIKOR Method for Solving Personnel Training," Int. J. Comput. Sci., vol. 1, no. 2, pp. 9-12, 2012.

[5] T. Bakshi, A. Sinharay, B. Sarkar, and S. K. Sanyal, "MCDM based project selection by F-AHP \& VIKOR," SEMCCO, vol. 7076 LNCS, no. PART 1, pp. 381-388, 2011.

[6] E. D. Coulter, J. Coakley, and J. Sessions, "The Analytic Hierarchy Process: A Tutorial for Use in Prioritizing Forest Road Investments to Minimize Environmental Effects," Int. J. For. Eng., vol. 17, no. 2, pp. 51-70, 2006

[7] Q. Yin, “An Analytical Hierarchy Process Model For The Evaluation Of College Experimental Teaching Quality," vol. 3, no. 2, pp. 59-65, 2013.

[8] A. Mardani, E. K. Zavadskas, K. Govindan, A. A. Senin, and A. Jusoh, "VIKOR technique: A systematic review of the state of the art literature on methodologies and applications," Sustain., vol. 8, no. 1, pp. 1-38, 2016.

[9] H. Jati and a Webometrics, "Comparison of University Webometrics Ranking Using Multicriteria Decision Analysis: TOPSIS and VIKOR Method," Word J. Int. Linguist. Assoc., pp. 1663-1669, 2012.

[10] Z. Zhang and C. Guo, "A VIKOR-Based Approach to Group Decision Making With Uncertain Preference Ordinals and Incomplete Weight Information," Informatica, vol. 27, no. 3, pp. 689-708, 2016.

[11] C. T. Sasanka and K. Ravindra, "Implementation of VIKOR Method for Selection of Magnesium Alloy to Suit Automotive Applications," Int. J. Adv. Sci. Technol., vol. 83, pp. 49-58, 2015.

[12] A. Basriani and Martina, "Pengaruh Promosi Jabatan Terhadap Kinerja Karyawan Pada PT Tasma Puja Di Pekanbaru," Menara Ilmu, vol. XI, no. 76, pp. 15-28, 2017.

[13] Saefudin and W. Sri, "Sistem Pendukung Keputusan Untuk Penilaian Kinerja Pegawai Menggunakan Metode Analytical Hierarchy Process (AHP) Pada RSUD Serang," J. Sist. Inf., vol. 1, no. 1, pp. 33-37, 2013.

[14] C. A. Poveda and M. G. Lipsett, "Weighting sustainable development indicators (SDIs) for surface mining operations using the analytical hierarchy process (AHP)," Int. J. Anal. Hierarchy Process, vol. 5, no. $2,2013$.

[15] J. M. Fernandes, S. P. Rodrigues, and L. A. Costa, "Comparing AHP and ELECTRE i for prioritizing software requirements," IEEE, 2015.

[16] Akmaludin, "Multicriteria Analysis Menentukan Point Weight Comparison Dalam Penetapan Decision Priority," vol. 11, no. 1, pp. $11-19,2015$.

[17] A. Ishizaka and A. Labib, "Review of the main developments in the analytic hierarchy process," vol. 38, no. 11, pp. 14336-14345, 2011.

[18] T. L. Saaty, "Decision making with the analytic hierarchy process," Int. J. Serv. Sci., vol. 1, no. 1, p. 83, 2008.

[19] T. L. Saaty, "Relative measurement and its generalization in decision making why pairwise comparisons are central in mathematics for the measurement of intangible factors the analytic hierarchy/network process," Rev. la Real Acad. Ciencias Exactas, Fis. y Nat. - Ser. A Mat., vol. 102, no. 2, pp. 251-318, 2008.

[20] S. Chupiphon and P. Janjira, "Compariosn Of MCDM Methods For Intercrop Selection In Rubber Plantations Chutiphon," J. ICT, vol. 1, no. 1, pp. 165-182, 2016.

[21] K. Renganath, "Supplier Selection Using Fuzzy MCDM Techniques : A Literature Review," IEEE, 2016.

[22] L. Markovic, M. Cvetkovic, and L. Milic-Markovic, "Multi-criteria decision-making when choosing variant solution of highway route at the level of preliminary design," Facta Univ. - Ser. Archit. Civ. Eng., vol. 11, no. 1, pp. 71-87, 2013.

[23] Y.-P. Ou Yang, H.-M. Shieh, J.-D. Leu, and G.-H. Tzeng, “a VikorBased Multiple Criteria Decision Method for Improving Information Security Risk," Int. J. Inf. Technol. Decis. Mak., vol. 8, no. 2, p. 267, 2009.

[24] K. Dashore, S. Singh Pawar, N. Sohani, and D. S. Verma, "Product Evaluation Using Entropy and Multi Criteria Decision Making Methods," Int. J. Eng. Trends Technol., vol. 4, no. May, pp. 21832187, 2013.

[25] S. K. Jarial and R. K. Garg, "Mcdm-Matrix Method-a Case Study for Commercial Vehicles in an Automobile Industry," MNK Publ., vol. 1, no. 4, pp. 337-341, 2012.

[26] A. Sciences, "Investment Destination Decision by Using the VIKOR 
Method in the European," Am. Int. J. Contemp. Res., vol. 6, no. 2, pp 16-24, 2016.

[27] K. G. D. Prasad, M. V Prasad, R. S. Kumar, V. S. D. Prasad, and K. V. S. J. Shanmukhi, "Kano-based VIKOR Decision model for Supplier Selection - A Case Study," Int. J. Mech. Eng., no. 2014, pp. 227-231, 2017.

[28] Ö. Yildirim, BF and Emrah, "Evaluating Potential Freight Villages in Istanbul Using Multi Criteria Decision Making Techniques," J. Logist. Manag., vol. 3, no. 1, pp. 1-10, 2014.

[29] Saaty TL, "How to Make a Decision The AHP," Eur. J. Oper. Res. vol. 1, no. 48, pp. 9-28, 1990. 